climatological observatories, including recording of potential evaporation, have been started by officers of the Grouse Inquiry at two sites in Glen Esk.

There is much of scientific interest also in the work of the Conservancy's Scientific Advisory Services, and in this field it has now been agreed that inquiries on physical or engineering aspects of coastal defence shall be referred to the Hydraulics Research Station of the Department of Scientific and Industrial Research and that the latter station will refer requests for advice on biological aspects to the Nature Conservancy. Work is now proceeding on establishing water-level gauges at key points in several Reserves, and a further year's observations on the series of small controlled catchments in the Moor House Reserve have confirmed the tentative conclusion that when the peat moor is undrained, ungrazed and unburnt, the sponge effect of the peat is enhanced and the run-off retarded and rendered more even through the seasons. While the Conservancy is taking the opportunity, in co-operation with the Botanical Society of the British Isles, and the Department of Biology of the University College of North Staffordshire and local naturalists to obtain data on the effects of toxic chemicals on roadside verges in Staffordshire, it is taking any action necessary to conserve flora and fauna in Staffordshire from the effects of the County Council's spraying programme and continues to urge the Council to bring its spraying programme into line with the practice recommended by the Ministry of Transport's Circular. The Wild Life Panel of the Interdepartmental Advisory Committee on Toxic Chemicals in Agriculture has been set up and will be asked to prepare guidance for industry on the type of data about wildlife hazards required when the Advisory Committee is notified about a product. The intensive study of red grouse in Glen Esk, Angus, undertaken by the University of Aberdeen, indicates that the grouse almost certainly adjust their own population density, through territorial behaviour and the exclusion of surplus birds, chiefly at two periods of the yearfirst in late autumn and then early in the spring before the breeding season. Variations in breeding density from year to year appear to depend more on the condition of the heather than on annual variations of breeding success, and a start has been made on the measurement of heather productivity. The marking of grey seal pups continued in the Farne Islands, West Wales, and the north of Scotland, and much is being learned about the movements to and from the main breeding colonies, the length of life, and the mortality among young seals. A special grant has now been made to the Conservancy for research on grey seals in relation to fisheries.

The section of the report dealing with conservation records an increase in the number of National Nature Reserves from 70 to 80 , while seven additional sites are managed as Local Nature Reserves with the advice of the Conservancy. Seven areas held for forestry purposes are similarly managed as Forest Nature Reserves with the advice of the Conservancy and two other areas enjoying statutory protection as wildfowl refuges have wardens through the support of the Conservancy. In Scotland, thirteen out of twenty-two National Nature Reserves have now been brought under comprehensive management plans approved by the Conservancy, and in England eighteen out of forty-two, and in Wales three out of sixteen. The variety of problems presented in managing the reserves is illustrated in the present report by fairly full accounts of the plans for the Cairngorms Reserve and the Cors Tregaron Reserve. In the latter, special attention is given to the cutting of poat, drainage and prevention of damage by fire.

The Conservancy's duties under its Charter have been fully recognized by the Secretary of State and provision made to strengthen its scientific and field staff to enable them to play their full part in informing and advising the Red Deer Commission, appointed under the Deer (Scotland) Act, 1959, on scientific aspects of its work. The Conservancy is also seeking to determine the patterm of migrating and wintering birds in the Bridgwater Bay Nature Reserve week by week and their daily and hourly movements between roosts and feeding areas, with a view of meeting objections made by local wildfowlers to the Conservancy's by-laws for this Reserve. This step illustrates one of the most important aspects of the Conservancy's work - the establishment of effective public relations. These are reviewed specially in this year's report, and the Conservancy affirms its view that the key to informing the general public about nature conservation must lie in the schools. This is a long-term approach and will need to be supplemented by other measures, particularly longterm, but the Conservancy is prepared to withstand temporary local unpopularity rather than take an easy course or accept a compromise which would jeopardize the maintenance for future generations of that part of the nation's scientific heritage with which it is entrusted. The Intelligence Unit established on May 4, 1959, by the Council for Nature should be of material assistance both in the provision of common services for biologists and naturalists and in solving such problems of public relations and public information.

\title{
SCIENTIFIC AND INDUSTRIAL RESEARCH IN NEW ZEALAND
}

\begin{abstract}
$\mathrm{T}$ HE report of the Department of Scientific and Industrial Research, New Zealand, for the year ended March 31, 1959, includes the Minister's Statement, the Council's report and that of the Secretary, together with the first annual report of the Ross Dependency Researeh Committee*. Lists of publications are given under departmental reports, and

* New Zealand. Report of the Department of Scientific and Industrial Research for the year ended 31 Mareh, 1959. Pp. 112. (Wellington: Government Printer, 1950.)
\end{abstract}

there are notes on the work of the incorporated research associations and on grant-aided research at the Canterbury Agricultural College, the Cawthron Institute, the Massey Agricultural College, the Seagrave Radio Research Station, University of Auck land, the Industrial Development Department snd the Rolleston Radio Field Station, University of Canterbury. Early in the year an Atomic Enorgy Committee was appointed as a sub-committee of the Couneil to advise on the Astablishment and operation. 
of a nuclear research institute, towards the first stage of development of which the Government has already approved the expenditure of $£ 240,000$. Expenditure in 1958-59 was $£ 1,658,149$ gross, compared with $£ 1,535,000$ in $1957-58$, the latter figure being $0 \cdot 142$ per cent of the national product, compared with 0.137 per cent in $1956-57$ and 0.173 per cent in 1949-50. Major expenditures were: Dominion Laboratory, £191,305 ; Dominion Physical Laboratory, £184,887; Geophysics Division, £164,865; Grasslands Division, $£ 101,145$; Soil Bureau, $£ 98,876$; Geological Survey, £96,359; and Plant Diseases Division, $£ 81,562$. Grants te research and allied institutions totalled $£ 165,282$, including $\mathfrak{1 3 2 , 2 0 0}$ to universities and agricultural colleges and $£ 83,061$ to research associations. The professional staff at March 31, 1959, was 390 compared with 383 in the previous year, with 435 technical (410), 175 clerical (165) and 65 other staff, but the Secretary points out that New Zealand employs fewer scientists in its major government research organizations than in 1952.

The Secretary's report reviews briefly work completed during the year. Facial eczema research of the Soil Bureau has established that Sporidesmium bakeri is a widespread saprophyte which colonizes dead material of a wide variety of plants and is a common invader of litter in pastures, and it appears there may be several strains of the fungus. The Grasslands Division is studying the environmental conditions favouring rapid growth and sporing of the fungus. The Plant Chemistry Division is studying the chemical composition of the lush autumn pasture responsible for 'hogget ill thrift' as part of a longterm study of the chemical factors which influence the quality of herbage for animal production, and the Grasslands Division has obtained encouraging results in the selection of parent plants to be used for the first nucleus seed supply of the new longrotation rye-grass. Use of $\mathrm{DDT}$ and $\mathrm{BHC}$, if applied at the appropriate time indicated by the life-history, has given promising results in control of adult Argentina stem weevil (Hyperodes griseus Hust) in rye-grasses, and a survey of two parasites liberated in the Nelson area against oak leaf miner (Lithocolletis messaniella Zell.) indicates that the winter parasite produces 85 per cent parasitism and promises to reduce damage by the leaf miner to insignificance.

Incorporation of 0.25 per cent dieldrin in glue for plywood, which has been recommended for protection against borer (Anobium punctatum), has become standard practice in the plywood industry. The search for a new apple rootstock to replace Northern Spy has now led to a new rootstock going into service, and much has also been done to reduce the virus infection in plum and apple root-stocks in nurseries and to assist the selection of virus-free budwood trees. Detailed studies of the freezing-point of pears have shown that this is likely to vary with different varieties and at different stages of ripeness and also from core to skin. The initial freezing-point of flesh near the core, the highest at which freezing can begin, is the temperature needed in practice by tho cool-store engineer. As a result of a programme of breeding for resistance to disease initiated in 1952 , improved varieties of cabbage, carrot, pole bean, glasshouse tomato and garden and field pea have already been released from the Division, and some 109 species, eight varieties and six hybrid weeds have been recorded, some now well-established and troublesome weeds, as additions to the weed flora of
New Zealand, some sixteen species being toxic to livestock. Considerable progress is reported of studies on the response of the hop plant to environmental factors, especially light and temperature, and at the Tobacco Research Station small refinements have been demonstrated, the combined effect of which in yield and protection against black root-rot and mosaic can be considerable.

A survey by the Soil Bureau on mineral colloids revealed extensive deposits of low-grade aluminium ore, while wild-life research has included a study of the role of parasites in the natural control of rabbit: populations and the inter-relations of cats, rats and petrels on the Little Barrier Island bird sanctuary. Forest surveys have shown that sufficient Dacrydium. biforme is present in the Westland area to satisfy a market demand for manool for ambreinolid of up to 20 tons a year for 25 years. Operating conditions have been established for a process for the manufacture of hydrochloric acid for casein precipitation from sodium chloride by ion exchange resin. Druing the year the geothermal section, transferred to the Geophysics Division from the Dominion Physical Laboratory, has evaluated the heat escaping naturally and mapped the boundary of the Wairakei geothermal area, and theoretical studies and laboratory experiments are in progress to clarify the mechanics of fluid convection in permeable rocks and of the flow of steam-water mixtures from the rocks into a drill-hole.

Much of the effort of the Geophysics Division was directed to the programme of the International Geophysical Year, and the 1958 teams at Scott Base and Hallett Station had an extremely successful year. Results from the magnetic observatories at Apia (Western Samoa) and Amberley (New Zealand) and the ionospheric observations extending from Raratonga (Cook Islands), through Godley Head (New Zealand) to the Antarctic on the phenomena observed with the Johnston Island nuclear explosions in August 1958 are still being collected and it is hoper that the study of the ionospheric and magnetic effects of the explosions will throw considerable light on the theory of magnetic storms and auroræ and the associated ionospheric disturbances. A systematic survey by the New Zealand Oceanographic Institute of the properties of the water of the Ross Sea, the animal life and the sediments from the east coast and the ice shelf to the 1,500 fathom line is providing a. general regional picture of fundamental significance, and the abundance of minute and lowly organisms in the shallower waters supports the larger and better-known animals of Antaretica, the penguins, skuas, seals, and the killer and other whales. A fairly extensive study of the southern aurora was undertaken, and this is now to be continued in a few specific experiments, chiefly at Invercargill, but also at Scott Base and Hallett Station, at Campbell Island and in Central Otago.

An analogue has been built which will simulate yield in single-story structures, and the results obtained in tests with six of the severest, earthquakes yet recorded indicate that if a structure is designed to yiold at a seismic coefficient of $0 \cdot 3$, the permanent set obtained in a severe earthquake is of the order $1 / 16-1 / 4 \mathrm{in}$. between floor and ceilings. Two experimental solar heaters are being built at the Dominion Physical Laboratory and a thorough study has been under. taken of the propagation of very low frequency (16 kc./s.) waves over great distances. Results are now being obtained with the tritium technique in the 
Division of Nuclear Science, and it should be possible to use this tracer to calculate the time for ground water to sink to depths at Wairakei and to be heated. The possibilities of radiocarbon as a tracer for studying the movements of water and gas underground in the thermal areas have also been investigated, and it has been shown that in the Wairakei area water takes probably considerably less than 40,000 years to travel from the surface to depths of $1,500 \mathrm{ft}$. Much assistance was given by the Geological Survey in the investigation and construction of large hydro-electric dams, while during the year electric resistance strain gauges were applied to a variety of problems, and the Applied Mathematics Laboratory and the Dominion Laboratory co-operated in investigations on the cause and prevention of outbreaks of fire in bales of greasy wool on board ship, and have shown that for a given air temperature there is a critical size for a volume of the material: a greater volume inevitably ignites. Further investigation of the lipids of red clover chloroplasts has shown that linolenic acid is accompanied by undecanoic acid, and the Wheat Research Institute has developed a rapid testing method-the Zeleny test-for baking quality.

\section{METHODS FOR THE EVALUATION OF THE ANTIBACTERIAL ACTIVITY OF SURFACE-ACTIVE COMPOUNDS}

$\mathrm{T}$ HE Society for Applied Bacteriology and the Microbiology Group of the Society of Chemical Industry held a joint meeting on January 13, with Mr. L. M. Miall in the chair, when a symposium on "Methods for the Evaluation of the Antibacterial Activity of Surface Active Compounds" was held.

The first speaker, Dr. J. G. Davis (London), reviewed technical aspects of the problem. Detergents differ in their bactericidal action; anionics and nonionics have little or no action, but are more effective detergents than the cationics, which have powerful antibacterial action. The amphoteric detergents have not yet been extensively tested but claims of powerful antibacterial action have been made. Of the cationic detergents, only the quaternary ammonium compounds are important in practice. They have only found wide application since 1935, when their strong germicidal powers were first emphasized, although they had been prepared in 1913. They are suitable for use with foods, as they are effective in dilute solution and are of low toxicity. They have a high degree of persistence, but traces remaining on food and utensils are not of public health significance. Non-ionic detergents have no action against bacteria, but compounds of these detergents with iodine, the iodophors, are active and are becoming important in the United States. Some of the amphoteric detergents, the betaine derivatives, are really 'internal quaternaries'.

Dr. Davis said that test methods should be as near as possible to the actual conditions in which the substance tested is used in practice. Laboratory tests should only be regarded as sorting tests. There are many variable factors, for example, the test organism; most of the work has been done with cultures of public health significance, Staphylococcus aureus, Streptococcus pyogenes, Strep. faecalis, Escherischia coli, Salmonella typhosa and Pseudomonas pyocyanea. The Gram-negative bacteria are usually more resistant than the Gram-positives, and Pseudomonas pyocyanea is usually the most resistant. For most test purposes, however, Staphylococcus aureus is the more suitable strain. Cultures maintained in the laboratory may be less resistant than freshly isolated types, and the method of cultivation may also affect the results. The number of cells is another variable, also whether or not they are clumped. Dr. Davis suggested an inoculum of 1 million cells, a convenient starting number when looking for 99.99 per cent kill, and thought it probably best to use normal laboratory culture media because the recovery of damaged cells was reported to be better than on special rich media.

In the Rideal-Walker test in particular, cell concentration is very important. Care is needed in examining tubes for growth, because low concentrations of quaternary ammonium compounds can cause turbidity in the medium. When testing quaternary ammonium compounds it is best to assume that a surface film is left on all the glass-ware, and to rinse it therefore with the test solution before doing the tests. Another difficulty is the increasingly powerful germicidal activity of slurries with increase in the amount of undissolved solid. The nature of the suspending liquid is also important, for example, the hardness of water can have very pronounced effects. The value of detergent sanitizers is often due largely to their detergent action; it is often sufficient to wash bacteria away. The alkalinity of a preparation may be of great value. The effect of organic matter on antibacterial action varies very greatly with the type of germicide. An addition of 4 per cent milk was suggested giving approximately 0.5 per cent solids, which is roughly equivalent to the amount of solids in dirty washing-up water.

In conclusion, Dr. Davis referred to the value of the Rideal-Walker test, which he said is the most important test in the history of disinfectant testing, but also the most misunderstood and abused. The Rideal-Walker test was originally devised for phenolic compounds; there is controversy on its applicability to quaternaries, and it is difficult to avoid commercial bias. The effect of quaternaries is largely due to their very great power of adsorption; in practical use there is no quenching of residual disinfectant with 'Lubrol W' or lecithin, which are used in laboratory tests. All buyers of disinfectants should receive adequate information on their potency, although it is not important to reveal the precise chemical composition. All manufacturers should declare the activity of the compound on at least two standard tests, which should be specified in detail.

In the discussion following the paper, it was remarked that Staphylococci are not necessarily more sensitive to quaternary ammonium compounds than the Gram-negatives, in fact some are more resistant than E. coli; the resistant Staphylococci usually come from hospitals. Whereas most quaternary ammonium compounds are ineffective against yeasts and moulds. 